\title{
A Fuzzy-AHP-QFD approach for achieving lean attributes for competitive advantages development, Case study: The Staam Sanat Company
}

\author{
Naghme Nobakht $^{\mathrm{a}^{*}}$ and Emad Roghanian ${ }^{\mathrm{b}}$
}

${ }^{a}$ Department of Engineering, Arak Branch, Islamic Azad University, Arak, Iran

${ }^{b}$ Department of Industrial Engineering, K.N.Toosi University of Technology, Tehran, Iran

\section{H R O N I C L E}

Article history:

Received April 23, 2012

Received in revised format

26 October 2012

Accepted 28 October 2012

Available online

October 292012

Keywords:

Lean production

Fuzzy Quality Function

Deployment (Fuzzy-QFD)

House of Quality (HOQ)

Fuzzy Analysis Hierarchy Process

(Fuzzy-AHP)

Fuzzy Logarithm Least Square

Method (Fuzzy-LLSM)

Area ranking

\begin{abstract}
A B S T R A C T
As one of the new producing approaches, lean production has brought in new opportunities for producers all around the world. Many producers have adopted the technique for surviving the growing world market. By combining competitive advantages, lean attributes, and lean enablers as three factors, the present study attempts to determine the most suitable enablers for improvement of lean attributes in a case study. Quality Function Deployment (QFD) in fuzzy environment and House of Quality (HOQ) matrix, successfully employed for development of new products, are adopted as approach of the study. Weights of competitive advantages, lean attributes and enablers are calculated through fuzzy analysis hierarchy process (FAHP), while fuzzy logarithmic least square method (LLSM) is used in calculation of the weights. Throughout the methodology, fuzzy logic is the basis for translating linguistic judgments required for the relationships and correlation matrix to numerical values. Moreover, final ranking of lean enablers is represented through area ranking method and taking into account various modes of decision makers' risk. Finally, a case study in automotive industry is introduced to demonstrate the implementation of the proposed methodology.
\end{abstract}

(C) 2013 Growing Science Ltd. All rights reserved.

\section{Introduction}

At the turn of the $21^{\text {st }}$ century, technology and science have been experiencing an unprecedented pace of development and every second has been characterized with a new theory. Many producers in this new world of fast changing technology and science have to deal with substantial changes in production techniques. However, some have managed to overcome the challenges through utilizing modern production concepts, techniques and approaches. One of the newest production techniques is lean production, which has powerful tools and enablers, and it holds substantial promises for producers (Alem Tabriz \& Rahimi, 2008).

Lean production has been considered as one of the initiatives implemented by many leading *Corresponding author

E-mail addresses: roz.nobakht@yahoo.com (N. Nobakht) 
businesses the whole world around and for keeping their competitive advantages in growing world market (Schonbergerm, 2007; Womack et al. 1990). It maintains big promises for considerable advantage for improvement of communication and integration within the organization and supply chain (Scherrer-Rathje et al., 2009). Lean enablers are considered as a set of tools, techniques and suggestions for implementation and execution of lean principles and helping business units to step toward leanness (de Treville \& Antonakis, 2006; Hopp \& Spearman, 2004; McLachlin, 1997; Narasimhan et al., 2006; Prince \& Kay, 2003; Shah \& Ward, 2003). Many business units either in manufacturing or service sectors have been helped by lean enablers to improve their competitiveness. Triggered by Toyota Production System, the application of Lean enablers has empowered various organizations to improve their quality, productivity and customer services, significantly (Jan Reizebos, 2009).

Taking into account, the wide groups of lean enablers and tools on one hand and limited organizational resources such as capital, time, human resource, etc. on the other hand, have not been able to use all these techniques and enablers. Therefore, one of the most important challenges is to select the most suitable and efficient tools and there have been many studies to solve this problem in recent years.

In this way, the present work attempts to develop an integrated approach, based on quality function deployment (QFD) and in particular HOQ technique, towards improving leanness of business units in two steps. The primary objective is to determine the relationship between the organization's competitive advantages and lean attributes in the first HOQ, and then ranking the most necessary and efficient lean attributes to achieve competitive advantages. The objective of the second step is to determine the effects of lean enablers on realization of lean attributes in the second HOQ and afterward ranking the most important and efficient lean enablers has been carried out to improve leanness of the organization. In addition, the present model uses fuzzy logic to minimize the gap between judgment and scoring and the reality. The proposed model of this paper uses competitive advantages, lean attributes and lean enablers based on fuzzy analytical hierarchy process (FAHP), while logarithmic least squares method (LLSM) is applied for calculating fuzzy weights. It is also noticeable that final ranking of lean enablers is calculated through area ranking and decision makers' risks in various modes. Finally, to show merits of the methodology, a case study is represented as well.

The rest of the paper is organized as follows. Section 2 presents a literature review of lean production, fuzzy logic, fuzzy-QFD, fuzzy-AHP, and fuzzy ranking followed by an introduction to Fuzzy-AHPQFD for increasing leanness of the organization in section 3. A case study in automotive industry is discussed in section 4 as a practical example along with outcomes of the model. Final section discusses results and recommendations for future works.

\section{Literature review}

\subsection{Lean production}

In recent years, intensification of challenges ahead of competitors at global level, have motivated many manufacturing firms to step towards new manufacturing techniques (Hall, 1987, Meredith \& McTavish, 1992). The concept of lean production is noticeable among many (Wormack \& Jones, 1996; Womack et al. 1995). The term "lean production" was first coined by Krafcik (1988); afterward implemented by Womack et al. (1990) to differentiate Toyota from the Western system of "mass production". Introduced by Toyota for the first time, lean production system is one of the leading approaches adopted by many businesses in the world to keep their competitive advantages in the growing global market. (Schonbergerm, 2007; Womack et al. 1990). As a multi-dimensional technique, lean production, in an integrated system, covers a wide range of management approaches and enablers. Lean production is powered by these practices, which results in end products at the 
same pace as customer demand and minimize the waste. (White et al., 1999; Abdulmalek \& Rajgopal, 2007; Monden, 1998; Nahmias,2001).

\subsection{Fuzzy logic and triangular fuzzy numbers (TFN)}

\subsubsection{Fuzzy logic}

Decision makers are normally faced with doubts and uncertainties where probability theory has been proved ineffective to handle the existing uncertainties (Bevilacqua et al. 2006). Specific reference to multi-criterion analysis means that, concerning a given attribute, the value of specific alternative may not be defined precisely; decision maker has no way or unwilling to precisely express his/her preferences. In such circumstances, linguistic terms are used for expressing opinions or evaluations and fuzzy logic holds the key for dealing with such uncertainty.

\subsubsection{TFN}

Among all kinds of fuzzy numbers, each may be the better choice for analyzing a given ambiguous structure; triangular fuzzy number (TFN) is one to name, which can be illustrated in a triplet $(a, b, c)$ (Fig. 1), where $\mathrm{a} \leq \mathrm{b} \leq \mathrm{c}$. By convention a non-fuzzy number is the case when $\mathrm{a}=\mathrm{b}=\mathrm{c}$. The membership function is defined as follows (Chamodrakas et al., 2009; Zimmermann, 1991):

$\mu_{N}(x): \begin{cases}(x-a) /(b-a), & x \in[a, b] \\ (c-x) /(c-b), & x \in[b, c] \\ 0 & \text { otherwise }\end{cases}$

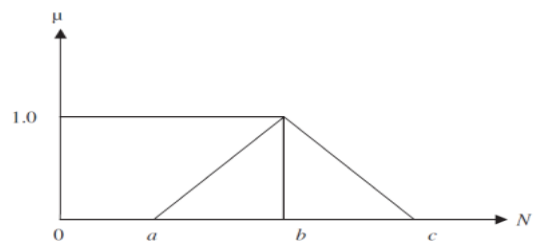

Fig. 1. Triangular fuzzy number (TFN)

For fuzzy calculations, see (Zimmermann, 1991).

\subsection{Fuzzy-QFD}

\subsection{1 $Q F D$}

As mentioned, HOQ of the QFD methodology, widely used as a powerful tool by leading companies in the world, is the primary basis for the proposed integrated method (Akao, 1990). QFD was first developed and applied in Kobe Shipyard of Mistubuishi Heavy industries, Japan 1972 (Hauser \& Clausin, 1988). As a customer driven design and manufacturing tool, the method has been faced with great attention and it has been used as a new field of product development for translating customers' requirement (Whats) into proper products engineering characteristics (Hows). For explaining reasons for success of QFD, its benefits, higher customer satisfaction, greater customer focus, shorter lead time, and knowledge preservation, is one dominant to name (Liu, 2009). Accurate construction of HOQ is an essential activity in QFD application and it is associated with determination of importance weights of customer requirements, the relationship matrix concerning customer requirements and engineering characteristics, and correlation matrix for engineering characteristics (Fig. 2). For HOQ modeling approach pleas look (Bottani \& Rizzi, 2006; Chan \& Wue, 2005; Fung et al., 2003). 


\subsubsection{Fuzzy-QFD}

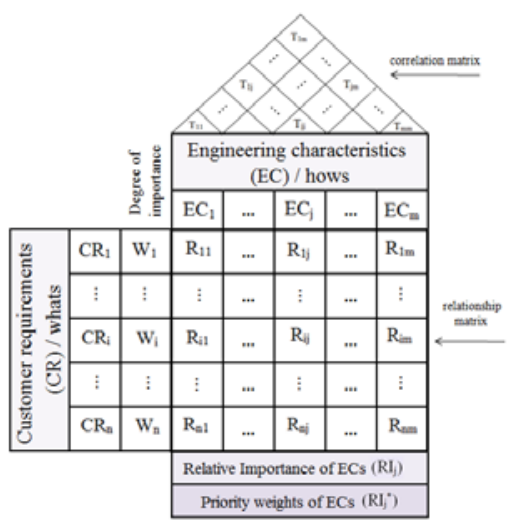

Fig. 2. The house of quality in QFD

Importance and weight of "Whats", relationship between each of the "Hows", and correlation between "hows" in the QFD approach are expressed according to customers/experts' judgments and information from linguistic expressions. One point regarding the approach is associated with continuous probability. Fuzzy logic regenerates inaccurate data and linguistic variables in mathematical forms implemented for decision-making situations. Using considerable capabilities of fuzzy logic and mathematics in QFD has been of great advantages for dealing with decision-making circumstances and improving reliability and accuracy of the results. Knowing this, many researchers have turned towards implementing fuzzy sets theory in QFD and consequently substantial development in fuzzy-QFD has been achieved recently (Liu, 2009).

To deal with the ambiguity in QFD operation, Khoo and Ho (1996) introduced an approach concentrated on the application of possibility theory and fuzzy arithmetic. A hybrid system has also been recommended by Fung et al. (1998) with its main purpose to unify the principles of QFD, AHP, and fuzzy set theory to determine design target. Focusing on ranking the relative importance of ECs in QFD, Shen et al. (2001) found that defuzzification method relatively induces large impacts on its ranking result. Fuzzy QFD was adopted in supply chain by Sohn and Choi (2001) for developing a fuzzy multi criteria decision making (MCDM) method for selecting a design featured with an optimal combination of reliability and customer satisfaction.

\subsubsection{Fuzzy-QFD calculations}

The main objective of fuzzy-QFD is to find final weight or importance of "hows". The general structure of house of quality matrix with fuzzy technique is equal to the mentioned house of quality. Fuzzy calculations about fuzzy-QFD and house of quality matrix are described in the following three steps (Bottani, 2009).

Step 1: Identification of importance of customer requirements (CRs) / "whats": First, $W_{i}$ as weighted importance of $i$-th $\mathrm{CR}$ is calculated directly by customers or experts using linguistic terms or obtained using more accurate techniques such as paired comparison and FAHP and other fuzzy weighting methods.

Step 2: Calculation of relative weight/importance of engineering characteristics (ECs) / "hows": $R I_{j}$ as relative importance of $j$-th $\mathrm{EC}$ is obtained based on its effect on CRs as follows:

$R I_{j}=\sum_{i=1}^{n} W_{i} \otimes R_{i j}, \quad j=1, \ldots, m$ 
where, $R_{i j}$ is fuzzy number, which represents the relation between $i$-th $\mathrm{CR}$ and $j$-th EC.

Step 3: Calculation of final weight of ECs: having correlation between ECs in the roof of the HOQ matrix obtained, following relation gives us its effect on $R I_{j}$ and consequently $R I_{j}{ }^{*}$ as final weigh of $j$ th EC.

$R I_{j}^{*}=R I_{j} \oplus \sum_{k=j} T_{k j} \otimes R I_{k}, \quad j=1, \ldots, m$

where, $T_{k j}$ is the degree of correlation between $k$-th and $j$-th $\mathrm{EC}$ and $R I_{k}$ is relative importance of $k$-th EC.

\subsection{Fuzzy-AHP}

\subsubsection{AHP}

Saaty (1980) is believed to be the first who introduced the idea of AHP and it has become a popular technique for the past three decades. It is comprised of three major operations including hierarchy construction, priority analysis and consistency verification (Ho, 2008) and QFD is one of the tools that are usually combined with AHP (Ho, 2008).

\subsubsection{Fuzzy-AHP}

While the traditional AHP requires precise judgment, the complexity and uncertainty features of the real-world decision problems make it impossible to reach exact judgments. A more realistic and natural approach, therefore, is to use a decision maker to replace precise comparisons with fuzzy judgments (Kuman \& Vaidya, 2006). Many methods have been developed for addressing fuzzy comparison matrices. For the first time, Van Laarhoven \& Pedrycz (1983), for instance, proposed a fuzzy LLSM by using triangular fuzzy comparison matrix to obtain triangular fuzzy. The method was further developed into trapezoidal fuzzy judgment and hierarchical analysis by Buckley (1985) and the implementation of geometric mean method for obtaining fuzzy weights regarding fuzzy comparison matrices was recommended. Boender et al. (1989) explained that the optimality of fuzzy weights could be tackled by the normalization method in the fuzzy LLSM and introduced a modification to the normalization method. In the same way, several modified and upgraded methods of frequency were introduced in this field. Wang et al. (2006), for instance, introduced a modified method for the fuzzy LLSM introduced by Laarhoven and Pedrycz (1983) and later modified by Boender et al. (1989).

\subsubsection{Fuzzy-LLSM}

To obtain fuzzy weight of an item, as the method instructs, following non-linear programming model must be solved for the paired comparison matrix where the item is compared in.

$\min \quad J=\sum_{i=1}^{n} \sum_{j=1, j \neq i}^{n} \sum_{k=1}^{\delta_{i j}}\left(\left(\ln w_{i}^{L}-\ln w_{j}^{U}-\ln a_{i j k}^{L}\right)^{2}+\left(\ln w_{i}^{M}-\ln w_{j}^{M}-\ln a_{i j k}^{M}\right)^{2}+\left(\ln w_{i}^{U}-\ln w_{j}^{L}-\ln a_{i j k}^{U}\right)^{2}\right.$

subject to

$w_{i}^{L}+\sum_{j=1, j \neq i}^{n} w_{j}^{U} \geq 1, w_{i}^{U}+\sum_{j=1, j \neq i}^{n} w_{j}^{L} \leq 1, \sum_{i=1}^{n} w_{i}^{M}=1, \quad i=1, \ldots, n$,

$\sum_{i=1}^{n}\left(w_{i}^{L}+w_{i}^{U}\right)=2$,

$w_{i}^{U} \geq w_{i}^{M} \geq w_{i}^{L} \geq 0$, 
where, $W_{i}=\left(w_{i}{ }^{L}, w_{i}{ }^{M}, w_{i}{ }^{U}\right)$ is fuzzy weight of $i$-th item compared in the paired comparison matrix and triangle fuzzy number $\tilde{a}_{i j k}=\left(l_{i j k}, m_{i j k}, u_{i j k}\right)$ is obtained comparing $i$-th and $j$-th item from $k$-th decision maker. Clearly for one decision maker, $k=1$ and thus $\tilde{a}_{i j}=\left(l_{i j}, m_{i j}, u_{i j}\right)$. This nonlinear model can be solved in all optimization softwares such as LINGO or MATLAB (Wang et al., 2006).

\subsection{Fuzzy ranking}

Fuzzy numbers ranking is an important concept in fuzzy sets theory in approximate reasoning, decision making, optimization, etc. Decision makers make their own estimation on the alternatives with fuzzy numbers and their choice finally results in fuzzy ranking. Therefore, the concept of optimized and the best choice is solely based on ranking or comparison of fuzzy numbers. There have been great efforts in this field, and variety of methods have been introduced for fuzzy ranking. Wang and Luo (2009) introduced one of the best and most commonly used ranking methods known as "area ranking" (Wang \& Luo 2009).

\subsubsection{Area ranking method}

Let $\tilde{A_{i}}$ be a fuzzy number for comparing or ranking. The gaps between $\tilde{A}_{i}$ and the negative ideal point and positive ideal point as well are shown in Fig. 3 as the two areas. They are called the left and right area.

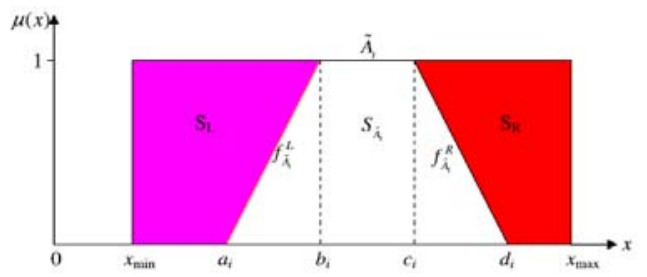

Fig. 3. Area ranking based on the positive and negative ideal points (Wang \& Luo, 2009)

The two areas are defined as:

$$
\begin{aligned}
& S_{L}(i)=\int_{x_{\min }}^{a_{i}} d x+\int_{a_{i}}^{b_{i}}\left(1-f_{\bar{i}_{i}}^{L}(x)\right) d x=\left(b_{i}-x_{\min }\right)-\int_{a_{i}}^{b_{i}} f_{\lambda_{i}}^{L}(x) d x \\
& S_{R}(i)=\int_{c_{i}}^{d_{i}}\left(1-f_{i_{i}}^{R}(x)\right) d x+\int_{d_{i}}^{x_{\max }} d x=\left(x_{\max }-c_{i}\right)-\int_{c_{i}}^{d_{i}} f_{\bar{\lambda}_{i}}^{R}(x) d x
\end{aligned}
$$

There are two new alternative ranking indices based on areas (RIA), which include DM's risk attitude and they use comparing and ranking fuzzy numbers as follows,

$$
\begin{aligned}
& R I A_{1}(i)=\frac{1}{2}\left[\left(\frac{S_{L}(i)}{x_{\max }-x_{\min }}\right) r_{L}(i)+\left(1-\frac{S_{R}(i)}{x_{\max }-x_{\min }}\right) r_{R}(i)\right] \\
& \operatorname{RIA}_{2}(i)=\frac{S_{L}(i) r_{L}(i)}{S_{L}(i) r_{L}(i)+S_{R}(i) r_{R}{ }^{\prime}(i)} \\
& r_{L}(i)=1+(\alpha-0.5) \frac{b_{i}-a_{i}}{x_{\max }-x_{\min }} \\
& r_{R}(i)=1+(\alpha-0.5) \frac{d_{i}-c_{i}}{x_{\max }-x_{\min }} \\
& r_{R}^{\prime}(i)=1-(\alpha-0.5) \frac{d_{i}-c_{i}}{x_{\max }-x_{\min }}
\end{aligned}
$$

where $r_{L}(i)$ is a left risk factor, $r_{R}(i)$ and $r_{R}^{\prime}(i)$ both are right risk factors defined to meet various goals, and $0 \leq \alpha \leq 1$ is the DM's attitude regarding risks with $\alpha=0.5$ for risk-neutral, $0.5<\alpha \leq 1$ for risk-seeking, and $0 \leq \alpha<0.5$ for risk-aversion. Both $R I A_{1}$ and $R I A_{2}$ are proper to be used for comparing and ranking. Higher fuzzy number ranking is obtained for bigger indices (Wang \& Luo, 2009). 


\section{Fuzzy-AHP-QFD model}

The framework applied by Fuzzy-AHP-QFD to achieve leanness has four major parts and they are depicted in Fig. 4. QFD and HOQ, in the approach, are translated from the field of new product development into lean context. Exploitation of HOQ for first competitive advantages to lean attribute is recommended, which has to be followed by lean attributes and in return to lean enablers. As it is clear in Fig. 5, the proposed approach demands creation of two HOQs. This section delves deeper into how to build the HOQs.

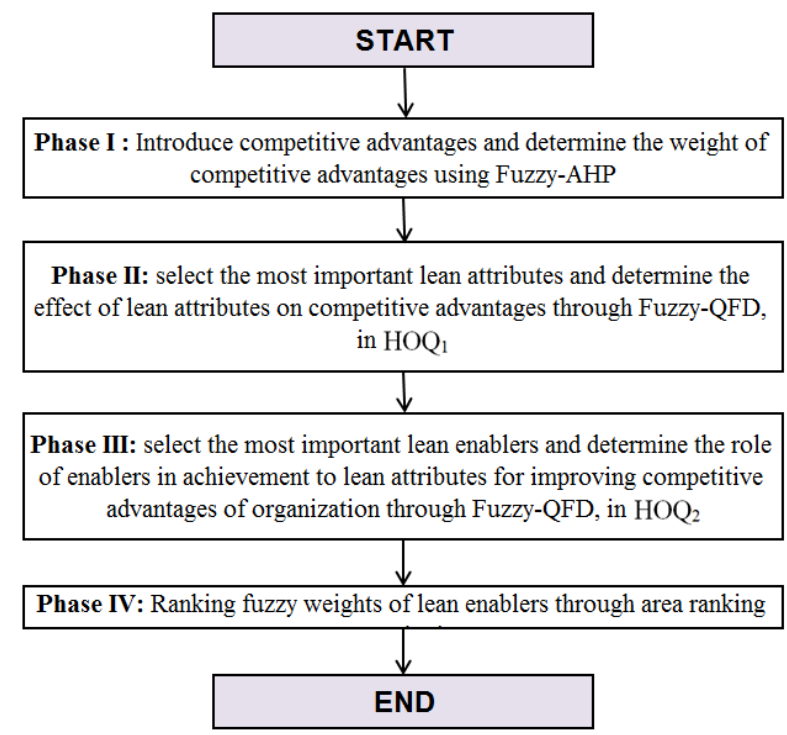

Fig. 4. Schematic representation of the algorithm

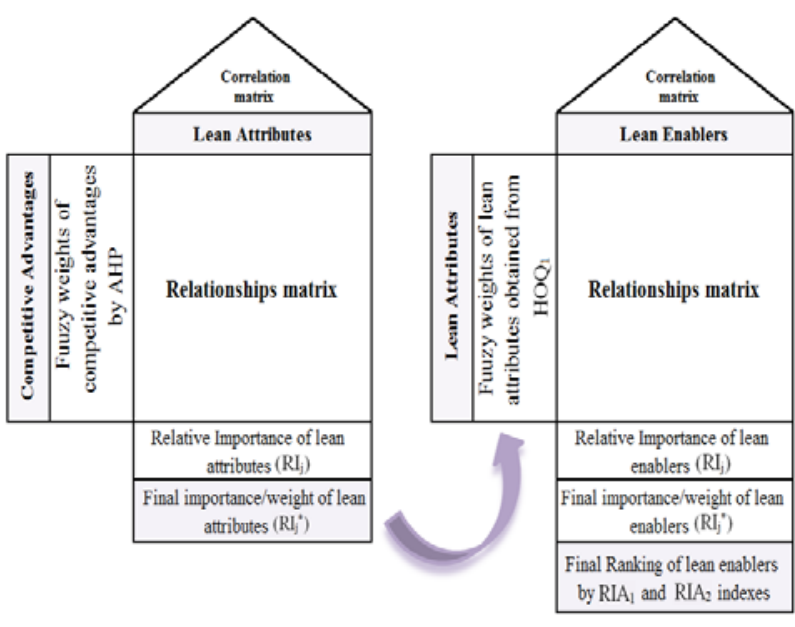

Fig. 5. Structure of the first and second house of quality

3.1 Phase I : Introduce competitive advantages and determine the weight of competitive advantages using Fuzzy-AHP

Competitive advantages: what guarantees survival of organizations in a competitive business environment and makes an organization outstanding among many are competitive advantages. Among the most important competitive advantages are improvement of standard and quality level, reduction of costs, growth of profitability, pace of production and delivery, variability, creativity and innovation, staff and customers satisfaction, responsiveness, market share, etc.(Bottani, 2009; Zarei et al., 2011). Majority of organizations, along with intensification of competition in the market, strive for realization of such advantages. Thanks to high efficiency for enabling, lean production, among many, is one of the approaches to make this possible. To remove waste of resources, increase profitability, reduce costs and improve performance as much as possible, a firm must use requirements and indices of leanness, and employs the most efficient lean enablers. This stage is constituted of 2 steps.

\section{Step 1: Identifying all competitive advantages of the organization and selecting the most important competitive advantages of organization}

Taking into account the necessity of reaching competitive advantages for each organization and the fact that the present work attempts to reach lean requirements for empowering competitive advantages of the organization, the first step is to select, based on experts' opinion and data collected through questionnaire and interviews, the most necessary and effeicient competitive advantages.

Step 2: Determining fuzzy weights of competitive advantages through pair comparison and using Fuzzy-AHP 
Paired comparison matrix and AHP are implemented to determine relative weights of competitive advantages. Proper linguistic variables are employed by the experts to carry out the comparison and determine relative importance and weight of advantages. Due to quantitative nature of linguistic variables, ambiguity is intrinsic to them and fuzzy logic helps removal of the ambiguities. Therefore, triangular fuzzy numbers are adopted to determine value of the variables. Linguistic variables in this work implemented for pairwise comparison, determination weights and corresponding fuzzy numbers are listed in Table 1.

\section{Table 1}

Linguistic variables and corresponding fuzzy numbers for expressing the relationships*.

\begin{tabular}{ll}
\hline Linguistic variables & Fuzzy numbers \\
\hline Equal importance & $(1 ; 1 ; 1)$ \\
Weak importance & $(2 / 3 ; 1 ; 3 / 2)$ \\
Moderate importance & $(3 / 2 ; 2 ; 5 / 2)$ \\
Strong importance & $(5 / 2 ; 3 ; 7 / 2)$ \\
Absolute importance & $(7 / 2 ; 4 ; 9 / 2)$ \\
\hline * bas
\end{tabular}

By ascertaining consistency of the judgments, an AHP method must be implemented for calculating fuzzy weights of competitive advantages. There are many methods introduced by researches to calculate weights of compared alternatives in pairwise comparison matrix. Some of these methods such as extent analysis introduced by Chang (1996), result in weights in form of crisp numbers with less accuracy, while others such as logarithmic least square (applied in the present work) result in weights in form of fuzzy numbers. Fuzzy weight of each competitive advantage, based on fuzzy logarithmic least square, has obtained through nonlinear programming model (Eq. (4)) and solved in a software package called Lingo. Fuzzy weights of the competitive advantages are listed in the second column of $\mathrm{HOQ}_{1}$ (Fig. 5).

\subsection{Phase II: select the most important lean attributes and determine the effect of lean attributes on competitive advantages through Fuzzy-QFD, in $H O Q_{1}$}

When competitive advantages (the final objective of the organization) and fuzzy weights of the advantages are obtained through Fuzzy-AHP, surveying lean attributes is under consideration afterward and there are three steps involved in this part.

\section{Step 1: Surveying attributes under consideration by the organization and selecting the best attributes (lean attributes) for minimizing wastes}

The final goal of lean production is to reduce costs through removing waste of resources in the system. The term "waste" refers to any activities with no value added, which is classified into seven groups in lean production system: excess production, waits, transportation, unnecessary process, inventory, movements and faulty products. To step toward being lean, organizations must focus on removal of wastes and consequently reduction of costs and more profitability and productivity. It is essential, therefore, to lead the firm towards removal of waste and improvement of the attributes, if it is supposed to be lean. Among many attributes about organizations' objectives and processes, those effective on removal or reduction of waste and consequently on leanness of organization, therefore, are adopted as most important lean attributes.

\section{Step 2: Determining effect of lean attributes on competitive advantages, in $\mathrm{HOQ}_{\mathbf{1}}$}

The firm normally tries to reach pre-set competitive advantages through concentrating the attributes determined as lean attributes and requirements. Thus, supervision of experienced experts for determination of the impacts of lean attributes of organization on competitive advantages is necessary. Fuzzy-QFD as one of strongest and most common quality management tools is implemented in this step. First HOQ, used in this work as pictured in Fig. 5, is comprised of 
competitive advantages in matrix rows (whats) and lean attributes in columns (hows). Central cells of HOQ, known as relationships matrix, are devoted to impact of lean attributes on competitive advantages. These cells ought to be filled out based on linguistic variables under experts' opinions. To ensure accuracy of the information, various techniques for filling out the relationships matrix are used so that all lean attributes from first competitive advantage viewpoint are compared in forms of pairwise comparison matrix and relative importance of the attributes are detected following determination of their impacts on the first advantage. Linguistic variables in Table 1 are used for pairwise comparison of lean attributes. In the same way, experts for the other competitive advantages perform pair comparisons of lean attributes in separate matrixes. By ascertaining consistency of the pairwise comparison matrixes, logarithmic least square (LLS) nonlinear programming model for each matrix is obtained through Eq. (4). Next, the models are solved using a simple mathematical optimization software and fuzzy weights of every attribute, relative to other attributes from the same competitive advantage, are calculated. The obtained figures are then inserted in the related row in $\mathrm{HOQ}_{1}$. The same process is repeated for all pairwise comparison matrixes and all rows of relationships matrix are filled out in the first HOQ matrix.

\section{Step 3: Determining effect of lean attributes on each other, in the roof of $\mathrm{HOQ}_{1}$ (correlation matrix)}

Among lean attributes, some have positive or negative correlation with others. That is, improvement of one attribute may influence others either positively or negatively. It is important, therefore, to study correlation among all the attributes. In doing so, experts' opinions and linguistic variables defined in Table 2 are used to determine correlations, if any, in the roof of $\mathrm{HOQ}_{1}$.

Table 2

Linguistic variables and corresponding fuzzy numbers for expressing the correlations*.

\begin{tabular}{lc}
\hline Linguistic variables & Fuzzy numbers \\
\hline Strong positive (SP) & $(0.7 ; 1 ; 1)$ \\
Positive (P) & $(0.5 ; 0.7 ; 1)$ \\
Negative (N) & $(0 ; 0.3 ; 0.5)$ \\
Strong negative (SN) & $(0 ; 0 ; 0.3)$ \\
\hline
\end{tabular}

* Source: adapted from Bottani and Rizzi (2006)

\section{Step 4: Fuzzy-QFD calculations for $\mathrm{HOQ}_{1}$ and obtaining final fuzzy weights and ranking of the lean attributes}

First, fuzzy weight of each competitive advantage is inserted according to matrix (Eq. 2) and relative fuzzy importance/weight of each lean attribute $\left(R I_{j}\right)$ is calculated. Afterward, correlations among lean attributes are employed in relative importance of each attribute $\left(R I_{j}\right)$ (Eq. 3) to obtain final importance/weights of the attributes $\left(R I_{j}^{*}\right)$.

3.3 Phase III: select the most important lean enablers and determine the role of enablers in achievement to lean attributes for improving competitive advantages of organization through Fuzzy$Q F D$, in $\mathrm{HOQ}_{2}$

This phase consists of four steps and deals with determining the most important enablers based on their role for achievement to the lean attributes defined earlier.

\section{Step 1: Surveying enablers used in the organization and electing the most effective lean enablers in achievement to lean attributes}

Lean production includes variety of tools and techniques known as lean enablers. Many researchers have introduced and employed various sets of techniques as lean enablers for implementation of the 
principles of leanness (Shah \& Ward, 2003; Browning \& Heath, 2009) Thus, there is a lack of a generally accepted set of tools as lean enablers. Taking into account impact in realization of lean attributes, some of the most important enablers used or potentially usable by the organization are selected in this step and they are appraised for weighting and prioritizing.

\section{Step 2: Determining effect of lean enablers on improvement of lean attributes, in $\mathrm{HOQ}_{2}$}

Determination of efficiency of each lean enabler on improvement of lean attributes is under consideration. Likewise, the second step of the previous phase, QFD and house of quality are applied. The second HOQ, as pictured in Fig. 5, is comprised of lean attributes in the rows (whats) and lean enables in the columns (hows). Likewise $\mathrm{HOQ}_{1}$, pair comparisons are implemented for determining the impact of lean enablers on lean attributes of relationships matrix. Therefore, every lean enabler in pairwise comparison matrix is compared based on its effect on the first attribute. Each linguistic variable list in Table 1 is used to express importance of every enabler relative to others. Similarly, pairwise comparison of lean enablers based on the other lean attributes is carried out in separate matrixes. By ascertaining consistency of the pairwise comparison matrixes, LLS nonlinear programming model for each matrix is obtained (Eq. 4). Afterward, the models are solved using an optimization technique and fuzzy weight of every attribute relative to other attributes from the same competitive advantage is calculated. The obtained figures are inserted in the related row in $\mathrm{HOQ}_{2}$. The same process is repeated for all pair comparison matrixes and all rows of relationships matrix in the $\mathrm{HOQ}_{2}$ were filled out.

\section{Step 3: Determining effect of lean enablers on each other, in the roof of $\mathrm{HOQ}_{2}$ (correlation matrix)}

A correlation between the enablers is common, so that implementation and execution of enablers may have either positive or negative impacts on other enablers. Experts used linguistic variables (Table 2) for determining correlation between lean enablers.

\section{Step 4: Fuzzy-QFD calculations for $\mathrm{HOQ}_{2}$ and obtaining final fuzzy weights of the lean enablers}

First, fuzzy weight of each lean attribute is inserted based on matrix (Eq. 2) and relative fuzzy importance /weight of each lean enabler $\left(R I_{j}\right)$ is obtained. Afterward, correlations among lean enablers are employed in relative importance of the enablers $\left(R I_{j}\right)$ (Eq. 3) to obtain final importance/weight of each enablers $\left(R I_{j}^{*}\right)$.

\subsection{Phase IV: Ranking fuzzy weights of lean enablers through area ranking method}

Fuzzy weights obtained in $\mathrm{HOQ}_{2}$ are utilized through a more accurate methods known as "area ranking" for final ranking of lean enablers. Two indices $R I A_{1}$ and $R I A_{2}$ are first calculated (Eq. 7 and Eq. 8), while $\alpha=0.5, \alpha=1, \alpha=0$ are used for risk-neutral, risk-seeking, and risk-aversion, respectively for inducing impact of decision maker's risk. Moreover, $S_{R}, S_{L}, r_{L}(i), r_{R}(i)$, and $r_{R}^{\prime}(i)$ (the last three elements are known as risk factors) are obtained through Eqs. (5-6) and Eqs. (9-11). Afterward, value of indices $R I A_{1}$ and $R I A_{2}$ for various values of $\alpha$ are calculated and ranking of lean enablers is obtained for each $\alpha$. Having final ranking of lean enablers, based on their impacts on lean attributes, and impact of lean attributes on empowerment of competitive advantages of the organization, the management can make a decision on the relative importance and priority of lean enablers. Consequently, the organization may concentrate, with less energy and time and higher efficiency, on the most important enablers with highest priority and stop wandering between varieties of techniques and lean enablers. In this way, the organization will have higher advantages and everincreasing development.

\section{Case study}

In this section, a numerical example is presented to picture performance and results of the model in 
practice. Considering pivotal impact of the automotive industry as the industry, which first developed the idea, our case study has been elected from this industry. Staam Sanat company, manufacturer of dynamo and automobile starts, has been selected for implementing the model.

Staam Sanat company (subsidiary to Ezaam industrial Group): This company aims on wide range of large quantities of products of the company and plans to penetrate into a world class producer of parts in global supply chain. The company is more concerned on implementation of lean principles and utilization of lean enablers. In what follows, all steps in the model are explained numerically and based on data from the company.

\subsection{Phase I: Identify competitive advantages and their weights through Fuzzy-AHP}

\section{Step 1: Identifying all competitive advantages and selecting the most important competitive advantages of the organization}

Seven advantages are identified based on competitive advantages introduced by Yusef et al. (2000) and Ren et al. (2003) and opinions of the team of experts. These competitive advantages are taken as macro goals of the organization, which are listed in Table 3 as the main competitive advantages.

\section{Table 3}

Competitive advantages, lean attributes and wastes related to each attributes, and lean enablers of Staam Sanat company

\begin{tabular}{|c|c|c|c|}
\hline Competitive Advantages & Lean Attributes & Waste related to each attributes & Lean Enablers \\
\hline Financial Resources & Education effectiveness & Waits & Continuous improvement (Kaizen) \\
\hline Market share & machineries failure & Waits & Preventive Maintenance (PM) \\
\hline Quality & Extra works & Unnecessary process & Supply Chain Management (SCM) \\
\hline success of planning & Production planning success rate & Excess production & Pull System (KANBAN production control) \\
\hline Human Resource & Actual inventory to standard inventory rate & Inventory & Failure Mode and Effect Analysis (FMEA) \\
\hline Products variety & Part Per Million (PPM) & faulty product & Job Rotation \\
\hline \multirow[t]{2}{*}{ After-sales services } & transportation cost to sale cost rate & Transportation & Human Resource Management (HRM) \\
\hline & extra costs of transportation rate & Movements & \\
\hline
\end{tabular}

\section{Step 2: Determining the fuzzy weights of competitive advantages through pair comparison by Fuzzy-AHP}

Seven advantages are compared using pair comparison matrix. Table 4 represents relative importance of the competitive advantages. As the table lists, the experts used linguistic variables and corresponding triangular fuzzy numbers for the comparison (Table 1). Afterward, fuzzy weights of competitive advantages were obtained through LLSM and nonlinear programming model (Eq. 4) for pair comparisons matrix in LINGO software.

\section{Table 4}

Fuzzy pair comparison matrix for competitive advantages.

\begin{tabular}{|c|c|c|c|c|c|c|c|}
\hline & $\begin{array}{l}\text { Financial } \\
\text { Resources }\end{array}$ & Market share & Quality & $\begin{array}{l}\text { success of } \\
\text { planning }\end{array}$ & $\begin{array}{l}\text { Human } \\
\text { Resource }\end{array}$ & $\begin{array}{l}\text { Products } \\
\text { variety }\end{array}$ & $\begin{array}{c}\text { After-sales } \\
\text { services }\end{array}$ \\
\hline Financial Resources & $(1,1,1)$ & $(2 / 3,1,3 / 2)$ & $(3 / 2,2,5 / 2)$ & $(2 / 3,1,3 / 2)$ & $(7 / 2,4,9 / 2)$ & $(3 / 2,2,5 / 2)$ & $(5 / 2,3,7 / 2)$ \\
\hline Market share & $(2 / 3,1,3 / 2)$ & $(1,1,1)$ & $(2 / 3,1,3 / 2)$ & $(3 / 2,2,5 / 2)$ & $(5 / 2,3,7 / 2)$ & $(5 / 2,3,7 / 2)$ & $(3 / 2,2,5 / 2)$ \\
\hline Quality & $(2 / 5,1 / 2,2 / 3)$ & $(2 / 3,1,3 / 2)$ & $(1,1,1)$ & $(3 / 2,2,5 / 2)$ & $(5 / 2,3,7 / 2)$ & $(3 / 2,2,5 / 2)$ & $(5 / 2,3,7 / 2)$ \\
\hline success of planning & $(2 / 3,1,3 / 2)$ & $(2 / 5,1 / 2,2 / 3)$ & $(2 / 5,1 / 2,2 / 3)$ & $(1,1,1)$ & $(5 / 2,3,7 / 2)$ & $(3 / 2,2,5 / 2)$ & $(5 / 2,3,7 / 2)$ \\
\hline Human Resource & $(2 / 9,1 / 4,2 / 7)$ & $(2 / 7,1 / 3,2 / 5)$ & $(2 / 7,1 / 3,2 / 5)$ & $(2 / 7,1 / 3,2 / 5)$ & $(1,1,1)$ & $(2 / 7,1 / 3,2 / 5)$ & $(2 / 5,1 / 2,2 / 3)$ \\
\hline Products variety & $(2 / 5,1 / 2,2 / 3)$ & $(2 / 7,1 / 3,2 / 5)$ & $(2 / 5,1 / 2,2 / 3)$ & $(2 / 5,1 / 2,2 / 3)$ & $(5 / 2,3,7 / 2)$ & $(1,1,1)$ & $(2 / 3,1,3 / 2)$ \\
\hline After-sales services & $(2 / 7,1 / 3,2 / 5)$ & $(2 / 5,1 / 2,2 / 3)$ & $(2 / 7,1 / 3,2 / 5)$ & $(2 / 7,1 / 3,2 / 5)$ & $(3 / 2,2,5 / 2)$ & $(2 / 3,1,3 / 2)$ & $(1,1,1)$ \\
\hline
\end{tabular}

$\mathrm{CI}=0.04 / \mathrm{CR}=0.03$

\subsection{Phase II: Select the most important lean attributes and determine the effect of lean attributes on competitive advantages using Fuzzy-QFD, in $H O Q_{1}$}

$\mathrm{HOQ}_{1}$ is pictured in Fig. 6 where first column of the matrix is dedicated to "whats" and the second column to their "fuzzy weights". (Fig. 6) 
Step 1: Identifying attributes under consideration in the organization and selecting the best attributes, as lean attributes, based on wastes reduction

When the team of the experts appraises the all attributes under consideration by the organization, the main attention, for determination of lean attributes, is shifted to the attributes effective on removal of wastes. Consequently, eight attributes are selected as the most important attributes (Table 3). First row of $\mathrm{HOQ}_{1}$ matrix (Fig. 6) lists the attributes ("hows").

\section{Step 2: determining effects of lean attributes on competitive advantages, in $\mathrm{HOQ}_{1}$}

The impacts of the eight lean attributes on achievement to the seven competitive advantages (HOQ $)_{1}$ are discussed in this step. $\mathrm{HOQ}_{1}$ (Fig. 6) is comprised of competitive advantages in the rows (whats) and lean attributes of the organization in the columns (hows). The impact of lean attributes on competitive advantages is listed in internal cell of $\mathrm{HOQ}_{1}$ (relationships matrix). For filling out the relationships matrix, the eight lean attributes are compared pairwise from the first competitive advantage viewpoint and relative importance of the attributes, regarding their effect on realization of the first competitive advantage, is obtained based on linguistic variables (Table 1). Fuzzy pair comparison matrix for lean attributes regarding the first competitive advantage (financial resources) is represented in Table 5.

In the same way, pair comparison of lean attributes is carried out based on the experts' opinion for other viewpoints of competitive advantages. The proposed model (Eq. 4) has been solved to calculate fuzzy weights of attributes in each matrix. The obtained fuzzy weights for the first matrix of pair comparison of attributes (financial resources) is listed on first row of $\mathrm{HOQ}_{1}$ matrix, while the other six rows of the relationships matrix are dedicated for the remaining six pair comparison matrixes solved by nonlinear programming model.

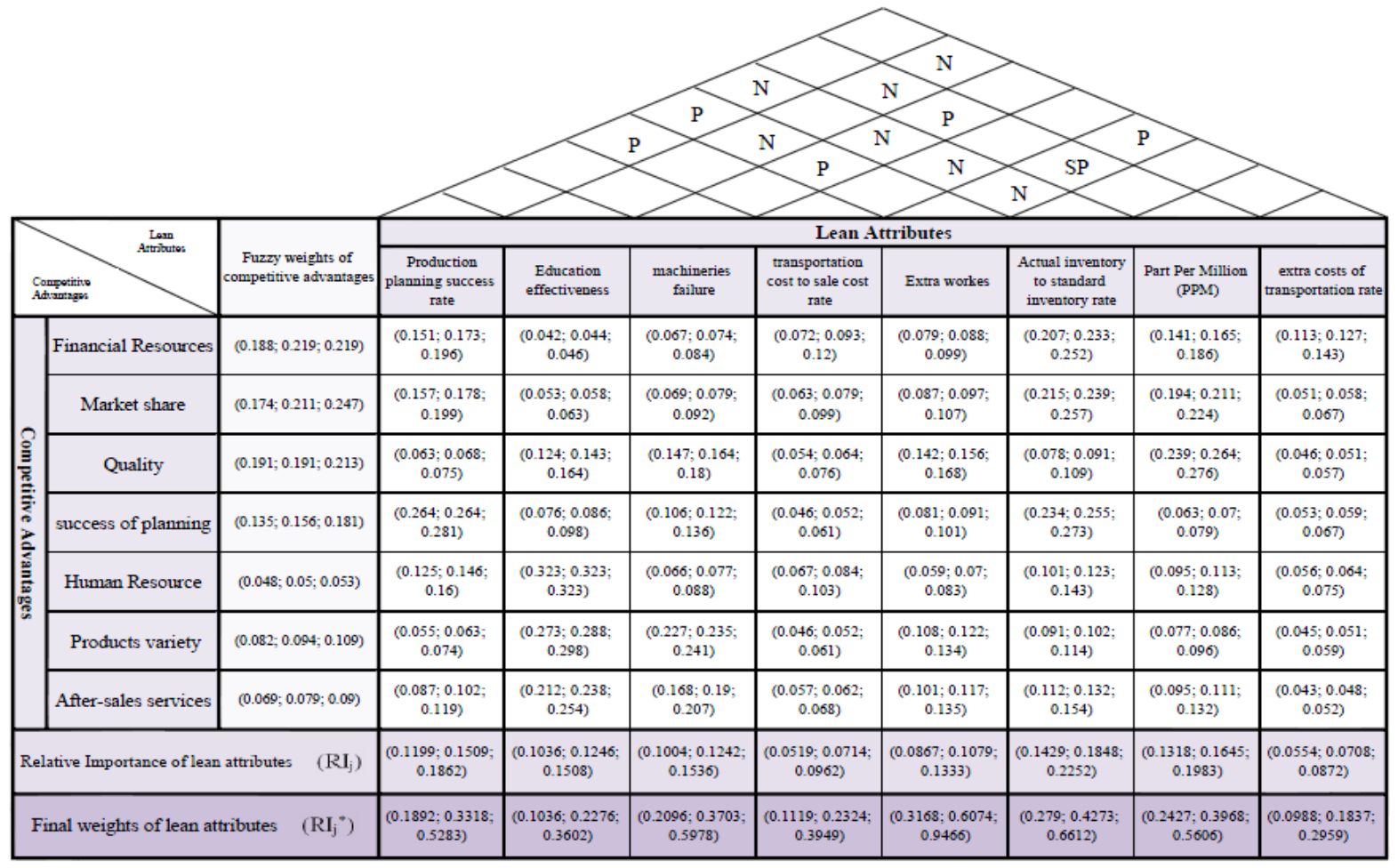

Fig. 6. The first HOQ 
Table 5

Fuzzy pair comparison matrix for lean attributes regarding the first competitive advantage (financial resources)

\begin{tabular}{|c|c|c|c|c|c|c|c|c|}
\hline $\begin{array}{l}\text { Financial } \\
\text { Resources }\end{array}$ & $\begin{array}{l}\text { Education } \\
\text { effectiveness }\end{array}$ & $\begin{array}{l}\text { machineries } \\
\text { failure }\end{array}$ & $\begin{array}{l}\text { Extra } \\
\text { works }\end{array}$ & $\begin{array}{l}\text { Production } \\
\text { planning } \\
\text { success rate }\end{array}$ & $\begin{array}{c}\text { Actual } \\
\text { inventory to } \\
\text { standard } \\
\text { inventory } \\
\text { rate } \\
\end{array}$ & $\begin{array}{l}\text { Part Per } \\
\text { Million } \\
\text { (PPM) }\end{array}$ & $\begin{array}{l}\text { transportation } \\
\text { cost to sale } \\
\text { cost rate }\end{array}$ & $\begin{array}{l}\text { extra costs of } \\
\text { transportation } \\
\text { rate }\end{array}$ \\
\hline $\begin{array}{c}\text { Education } \\
\text { effectiveness }\end{array}$ & $(1,1,1)$ & $(2 / 7,1 / 3,2 / 5)$ & $(2 / 7,1 / 3,2 / 5)$ & $(2 / 9,1 / 4,2 / 7)$ & $(2 / 9,1 / 4,2 / 7)$ & $(2 / 7,1 / 3,2 / 5)$ & $(2 / 3,1,3 / 2)$ & $(2 / 9,1 / 4,2 / 7)$ \\
\hline $\begin{array}{l}\text { machineries } \\
\text { failure }\end{array}$ & $(5 / 2,3,7 / 2)$ & $(1,1,1)$ & $(2 / 5,1 / 2,2 / 3)$ & $(2 / 7,1 / 3,2 / 5)$ & $(2 / 5,1 / 2,2 / 3)$ & $(2 / 5,1 / 2,2 / 3)$ & $(2 / 3,1,3 / 2)$ & $(2 / 7,1 / 3,2 / 5)$ \\
\hline Extra works & $(5 / 2,3,7 / 2)$ & $(3 / 2,2,5 / 2)$ & $(1,1,1)$ & $(2 / 7,1 / 3,2 / 5)$ & $(2 / 7,1 / 3,2 / 5)$ & $(2 / 5,1 / 2,2 / 3)$ & $(2 / 3,1,3 / 2)$ & $(2 / 5,1 / 2,2 / 3)$ \\
\hline $\begin{array}{l}\text { Production } \\
\text { planning } \\
\text { success rate }\end{array}$ & $(7 / 2,4,9 / 2)$ & $(5 / 2,3,7 / 2)$ & $(5 / 2,3,7 / 2)$ & $(1,1,1)$ & $(2 / 3,1,3 / 2)$ & $(2 / 5,1 / 2,2 / 3)$ & $(2 / 3,1,3 / 2)$ & $(3 / 2,2,5 / 2)$ \\
\hline $\begin{array}{c}\text { Actual } \\
\text { inventory to } \\
\text { standard } \\
\text { inventory } \\
\text { rate }\end{array}$ & $(7 / 2,4,9 / 2)$ & $(3 / 2,2,5 / 2)$ & $(5 / 2,3,7 / 2)$ & $(2 / 3,1,3 / 2)$ & $(1,1,1)$ & $(3 / 2,2,5 / 2)$ & $(7 / 2,4,9 / 2)$ & $(3 / 2,2,5 / 2)$ \\
\hline $\begin{array}{l}\text { Part Per } \\
\text { Million } \\
\text { (PPM) }\end{array}$ & $(5 / 2,3,7 / 2)$ & $(3 / 2,2,5 / 2)$ & $(3 / 2,2,5 / 2)$ & $(3 / 2,2,5 / 2)$ & $(2 / 5,1 / 2,2 / 3)$ & $(1,1,1)$ & $(2 / 3,1,3 / 2)$ & $(3 / 2,2,5 / 2)$ \\
\hline $\begin{array}{l}\text { transportation } \\
\text { cost to sale } \\
\text { cost rate }\end{array}$ & $(2 / 3,1,3 / 2)$ & $(2 / 3,1,3 / 2)$ & $(2 / 3,1,3 / 2)$ & $(2 / 3,1,3 / 2)$ & $(2 / 9,1 / 4,2 / 7)$ & $(2 / 3,1,3 / 2)$ & $(1,1,1)$ & $(2 / 3,1,3 / 2)$ \\
\hline $\begin{array}{l}\text { extra costs of } \\
\text { transportation } \\
\text { rate }\end{array}$ & $(7 / 2,4,9 / 2)$ & $(5 / 2,3,7 / 2)$ & $(3 / 2,2,5 / 2)$ & $(2 / 5,1 / 2,2 / 3)$ & $(2 / 5,1 / 2,2 / 3)$ & $(2 / 5,1 / 2,2 / 3)$ & $(2 / 3,1,3 / 2)$ & $(1,1,1)$ \\
\hline
\end{tabular}

Step 3: Determining mutual effect of lean attributes in the roof of $\mathrm{HOQ}_{1}$ (correlation matrix)

There are positive/negative correlations among some of lean attributes, between machineries failure and PPM, for instance, there is a positive correlation; so that, the more failure of the machineries, the more rate of broken products and vice versa. In addition, a negative correlation is found between education effectiveness index and rate of extra works. This is to say, rate of parallel works declines with more efficient education. Linguistic variables and equivalent triangular fuzzy numbers (Table 2) are used for finding correlation, if any, between the lean attributes.

\section{Step 4: Fuzzy QFD calculations for $\mathrm{HOQ}_{1}$ and obtaining final fuzzy weights and ranking of the lean attributes}

Fuzzy weight of each competitive advantage is first implemented in the relationships matrix (Eq. 2) for obtaining relative fuzzy importance/weight of each lean attribute $\left(R I_{j}\right)$. Afterward, correlations between the lean attributes were implemented on relative importance of each attribute (RIj) (Eq. 3) and final importance/weight of each attribute $\left(R I_{j}{ }^{*}\right)$ was obtained.

4.3 Phase III: Choose the most important lean enablers and determine the effect of enablers on achievement to lean attributes and empowerment of competitive advantages consequently through Fuzzy-QFD, in $\mathrm{HOQ}_{2}$

Determination of the most important lean enablers, based on their role in realization of lean attributes obtained in previous step, is under consideration. To this end, the $\mathrm{HOQ}_{2}$ pictured in Fig. 7 is utilized.

Step 1: Identifying enablers under consideration by the organization and selecting the best enablers for finding the lean attributes

A list of enablers is prepared through literature review, and then the experts examine them. Considering available tools and techniques or potentially applicable techniques in the organization seven lean enablers are selected as the most important and essential factors (Table 3).

\section{Step 2: determining effect of lean enablers on improvement of lean attributes, in $\mathrm{HOQ}_{2}$}

The second HOQ (Fig. 7), comprised of lean attributes on the rows (whats) and lean enablers on the 
columns (hows), is used for determining the impacts of enablers on improvement of lean attributes. Likewise the previous phase, pair comparisons are employed for filling out relationships matrix. So that, lean enablers in a pair comparison matrix are compared pairwise, regarding their effect on the first lean attribute, and relative importance of the enablers is expressed by linguistic variables list in Table 1. Lean enablers pair comparison matrix from the first lean attribute viewpoint - education effectiveness- is represented in the Table 6.

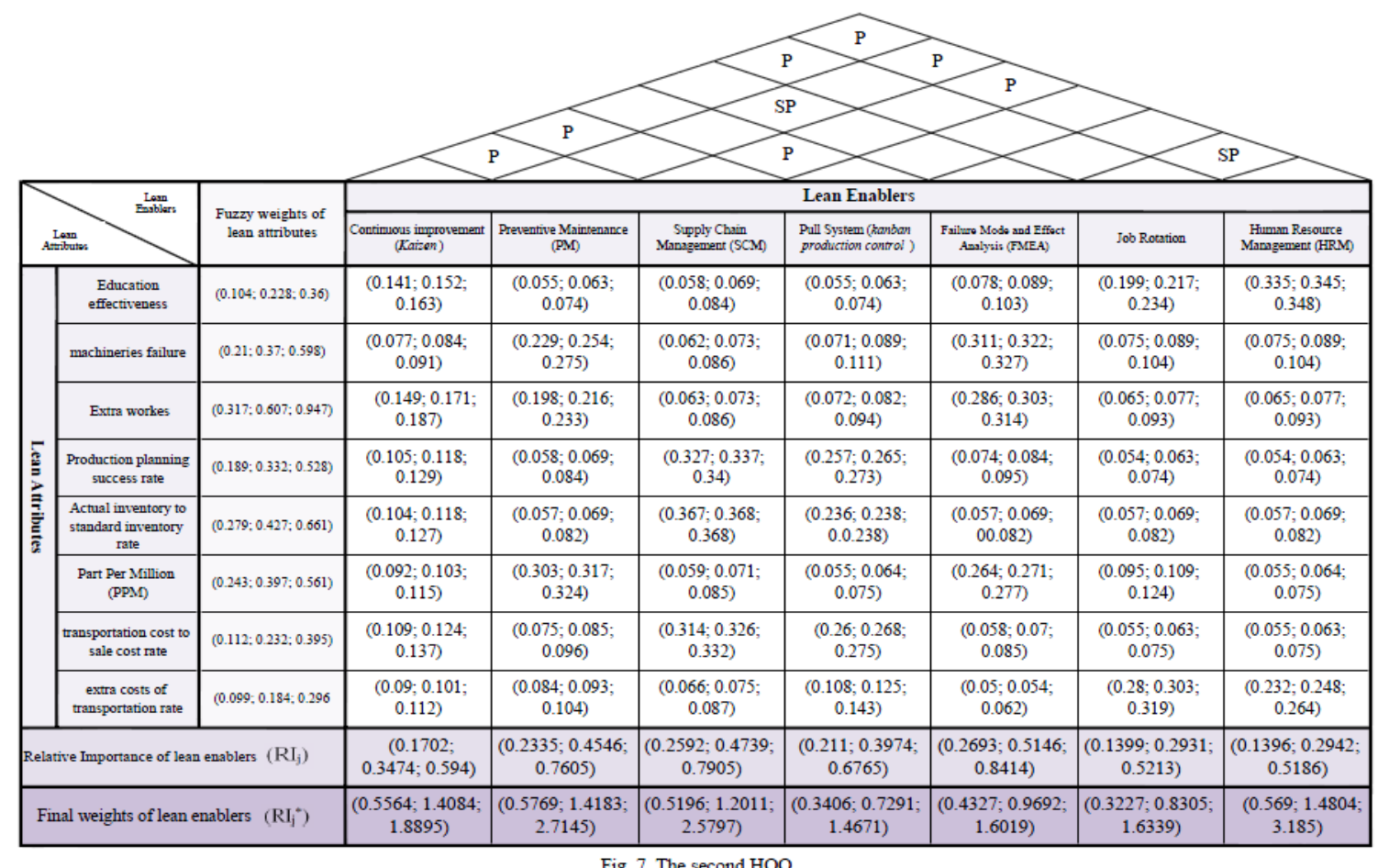

Table 6

Fuzzy pair comparison matrix for lean enablers regarding the first lean attribute (education effectiveness).

\begin{tabular}{|c|c|c|c|c|c|c|c|}
\hline Education effectiveness & $\begin{array}{c}\text { Continuous } \\
\text { improvement } \\
\text { (Kaizen) }\end{array}$ & $\begin{array}{l}\text { Preventive } \\
\text { Maintenance } \\
\text { (PM) }\end{array}$ & $\begin{array}{l}\text { Supply Chain } \\
\text { Management } \\
\text { (SCM) }\end{array}$ & $\begin{array}{l}\text { Pull System } \\
\text { (kanban } \\
\text { production } \\
\text { control) }\end{array}$ & $\begin{array}{c}\text { Failure Mode } \\
\text { and Effect } \\
\text { Analysis } \\
\text { (FMEA) }\end{array}$ & Job Rotation & $\begin{array}{c}\text { Human } \\
\text { Resource } \\
\text { Management } \\
\text { (HRM) }\end{array}$ \\
\hline $\begin{array}{c}\text { Continuous improvement } \\
\text { (Kaizen) }\end{array}$ & $(1,1,1)$ & $(5 / 2,3,7 / 2)$ & $(5 / 2,3,7 / 2)$ & $(5 / 2,3,7 / 2)$ & $(3 / 2,2,5 / 2)$ & $(2 / 5,1 / 2,2 / 3)$ & $(2 / 9,1 / 4,2 / 7)$ \\
\hline $\begin{array}{l}\text { Preventive Maintenance } \\
\text { (PM) }\end{array}$ & $(2 / 7,1 / 3,2 / 5)$ & $(1,1,1)$ & $(2 / 3,1,3 / 2)$ & $(2 / 3,1,3 / 2)$ & $(2 / 5,1 / 2,2 / 3)$ & $(2 / 7,1 / 3,2 / 5)$ & $(2 / 9,1 / 4,2 / 7)$ \\
\hline $\begin{array}{l}\text { Supply Chain Management } \\
\text { (SCM) }\end{array}$ & $(2 / 7,1 / 3,2 / 5)$ & $(2 / 3,1,3 / 2)$ & $(1,1,1)$ & $(2 / 3,1,3 / 2)$ & $(2 / 3,1,3 / 2)$ & $(2 / 7,1 / 3,2 / 5)$ & $(2 / 9,1 / 4,2 / 7)$ \\
\hline $\begin{array}{l}\text { Pull System (kanban } \\
\text { production control) }\end{array}$ & $(2 / 7,1 / 3,2 / 5)$ & $(2 / 3,1,3 / 2)$ & $(2 / 3,1,3 / 2)$ & $(1,1,1)$ & $(2 / 5,1 / 2,2 / 3)$ & $(2 / 7,1 / 3,2 / 5)$ & $(2 / 9,1 / 4,2 / 7)$ \\
\hline $\begin{array}{l}\text { Failure Mode and Effect } \\
\text { Analysis (FMEA) }\end{array}$ & $(2 / 5,1 / 2,2 / 3)$ & $(3 / 2,2,5 / 2)$ & $(2 / 3,1,3 / 2)$ & $(3 / 2,2,5 / 2)$ & $(1,1,1)$ & $(2 / 7,1 / 3,2 / 5)$ & $(2 / 9,1 / 4,2 / 7)$ \\
\hline Job Rotation & $(3 / 2,2,5 / 2)$ & $(5 / 2,3,7 / 2)$ & $(5 / 2,3,7 / 2)$ & $(5 / 2,3,7 / 2)$ & $(5 / 2,3,7 / 2)$ & $(1,1,1)$ & $(2 / 5,1 / 2,2 / 3)$ \\
\hline $\begin{array}{c}\text { Human Resource } \\
\text { Management (HRM) }\end{array}$ & $(7 / 2,4,9 / 2)$ & $(7 / 2,4,9 / 2)$ & $(7 / 2,4,9 / 2)$ & $(7 / 2,4,9 / 2)$ & $(7 / 2,4,9 / 2)$ & $(3 / 2,2,5 / 2)$ & $(1,1,1)$ \\
\hline
\end{tabular}

In the same way, pair comparison of lean enablers is carried out regarding other lean attributes in separate matrixes. Nonlinear programming model (4) was solved using an optimization technique for 
each one of eight pairwise comparison matrixes and relationships matrix is filled out like the previous phase.

\section{Step 3: Determining mutual effect of lean enablers in the roof of $\mathrm{HOQ}_{2}$ (correlation matrix)}

There are positive/negative correlations among some of lean enablers. Between preventive maintenance(PM) and failure mode and effect analysis (FMEA), for instance, there is a strong positive correlation; so that, FMEA helps spotting more risky parts of machineries and equipments for better allocation of preventive maintenance measures and avoiding failures or control frequency and intensity of failure. Therefore, FMEA improves preventive maintenance. Correlations between lean enablers determined by the experts using linguistic variables (Table 2) are inserted in the roof of $\mathrm{HOQ}_{2}$.

\section{Step 4: Fuzzy QFD calculations for $\mathrm{HOQ}_{2}$ and obtaining final fuzzy weights and ranking of the lean enablers}

Fuzzy weight of each lean attribute is first implemented in the relationships matrix (Eq. 2) for obtaining relative fuzzy Importance/weight of each lean enabler $\left(R I_{j}\right)$. Afterward, correlations between the lean enablers are implemented on relative importance of the enablers (RIj) (Eq. 3) and final importance/weight of each enabler $\left(R I_{j}^{*}\right)$ was obtained.

\subsection{Phase IV: Ranking fuzzy weights of lean enablers through area ranking method}

Final ranking of fuzzy enablers is carried out as explained in phase 4 in section 3 . Noticeable point is that two ideal positive $\left(x_{\max }\right)$ and negative $\left(x_{\min }\right)$ points are required by the method. In this case $x_{\max }$ and $x_{\min }$ were 3.185 and 0.3227 , respectively. The former represents the highest right side and the latter represents the lowest left side among final fuzzy weights of lean enablers. $S_{L}$ and $S_{R}$ are obtained through Eq. (5) and Eq. (6). Fig. 4 pictures points $x_{\max }, x_{\min }$ and also spaces $\mathrm{S}_{\mathrm{L}}$ and $\mathrm{S}_{\mathrm{R}}$. Eqs. (9-11) are used for obtaining $r_{L}(i), r_{R}(i)$ and $r_{R}{ }^{\prime}(i)$, respectively. The indices $R I A_{1}$ and $R I A_{2}$ are ranked based on Eq (7) and Eq. (8). Having $R I A_{1}$ and $R I A_{2}$, lean enablers of the company are ranked in different modes of risk-neutral $\alpha=0.5$, risk-seeking $\alpha=1$, and risk-aversion $\alpha=0$ (Table 7).

\section{Table 7}

Final ranking of lean enablers through area ranking method in three different decision makers' risk modes

\begin{tabular}{|c|c|c|c|c|c|c|c|c|c|}
\hline \multirow{2}{*}{ Lean Enablers } & \multirow[b]{2}{*}{$\begin{array}{l}\text { Fuzzy weights of lean enablers } \\
\left(\mathrm{RI}_{\mathrm{j}}^{*}\right)\end{array}$} & \multirow{2}{*}{$S_{L}(i)$} & \multirow{2}{*}{$S_{R}(i)$} & \multicolumn{2}{|c|}{ risk-neutral $(\alpha=0.5)$} & \multicolumn{2}{|c|}{ risk-seeking $(\alpha=1)$} & \multicolumn{2}{|c|}{ risk-aversion $(\alpha=0)$} \\
\hline & & & & $R I A_{1}$ & $R I A_{2}$ & $R I A_{1}$ & $R I A_{2}$ & $R I A_{1}$ & $R I A_{2}$ \\
\hline $\begin{array}{l}\text { Continuous } \\
\text { improvement (Kaizen) }\end{array}$ & $(0.5564 ; 1.4084 ; 1.8895)$ & 0.6597 & 1.53605 & 0.34692 & 0.29344 & 0.35009 & 0.38354 & 0.25218 & 0.31029 \\
\hline $\begin{array}{l}\text { Preventive } \\
\text { Maintenance (PM) }\end{array}$ & $(0.5769 ; 1.4183 ; 2.7145)$ & 0.6749 & 1.1186 & 0.42249 & 0.376303 & 0.47218 & 0.50879 & 0.2956 & 0.3362 \\
\hline $\begin{array}{l}\text { Supply Chain } \\
\text { Management (SCM) }\end{array}$ & $(0.5196 ; 1.2011 ; 2.5797)$ & 0.53765 & 1.2946 & 0.36777 & 0.30044 & 0.37972 & 0.4449 & 0.22771 & 0.29064 \\
\hline $\begin{array}{l}\text { Pull System (kanban } \\
\text { production control ) }\end{array}$ & $(0.3406 ; 0.7291 ; 1.4671)$ & 0.21215 & 2.0869 & 0.17251 & 0.092277 & 0.11081 & 0.19249 & 0.07744 & 0.15253 \\
\hline $\begin{array}{l}\text { Failure Mode and } \\
\text { Effect Analysis } \\
\text { (FMEA) }\end{array}$ & $(0.4327 ; 0.9692 ; 1.6019)$ & 0.37825 & 1.89945 & 0.23472 & 0.166067 & 0.1967 & 0.25905 & 0.13979 & 0.20949 \\
\hline Job Rotation & $(0.3227 ; 0.8305 ; 1.6339)$ & 0.26355 & 1.9528 & 0.20491 & 0.118912 & 0.14597 & 0.23129 & 0.09735 & 0.17853 \\
\hline $\begin{array}{l}\text { Human Resource } \\
\text { Management (HRM) }\end{array}$ & $(0.569 ; 1.4804 ; 3.185)$ & 0.702 & 0.8523 & 0.47374 & 0.45165 & 0.57621 & 0.59782 & 0.34795 & 0.34967 \\
\hline
\end{tabular}


Higher values of $R I A_{1}$ and $R I A_{2}$ hint higher ranking for lean enabler and as listed in Table $8, R I A_{l}$ and $R I A_{2}$ ranking for risk-neutral and risk-seeking modes is similar and slightly differs for risk-aversion mode.

\section{Conclusion and recommendations}

An integrated approach of Fuzzy-AHP-QFD characterized by utilization of QFD and in particular HOQ for improvement of leanness in the organization was discussed. Importance of competitive advantages of each organization and many benefits obtained through lean enablers and tools are not deniable. The approach represented a general framework comprised of two consecutive HOQ to achieve the best enablers through combining three factors of competitive advantages, lean attributes and lean enablers. This guarantees the highest efficiency in realization of lean requirements and attributes and, therefore, achievement of more and more competitive advantages. In general term, achievement and advantages of each phase can be summarized as follows.

The most important competitive advantages of the organization were determined in phase 1 based on market and the company condition. In addition, relative weight (importance) and ranking of each competitive advantage were obtained. In phase 2, the most important lean attributes for removal of wastes in the organization and their effect on realization of competitive advantages (pair comparison and LLSM) in $\mathrm{HOQ}_{1}$, and correlations between the lean attributes and effect of the correlation on the weights were dealt with. Fuzzy weights of the lean attributes and their ranking were also obtained in this phase. Afterward, phase 3 focused on determining the most effective lean enablers and calculating the effect of enablers on the attributes through pair comparisons and LLSM method in $\mathrm{HOQ}_{2}$. Moreover, correlations between the enablers and role of the correlations on final weight of each enabler were discussed in this phase and fuzzy weights and ranking of the enablers were calculated. Finally, in phase 4, final fuzzy weight ranking of each enabler was carried out through area ranking in three different decision makers modes including risk-neutral, risk-seeking and riskaversion (Table 8).

\section{Table 8}

Final fuzzy weights of lean enablers and their ranking in three different risk modes.

\begin{tabular}{|c|c|c|c|c|}
\hline \multirow[b]{2}{*}{ Lean Enabler } & \multirow[b]{2}{*}{ Final fuzzy weights } & \multicolumn{3}{|c|}{ Final ranking of lean enablers } \\
\hline & & $\begin{array}{c}\text { risk-neutral } \\
\quad(\alpha=0.5)\end{array}$ & $\begin{array}{c}\text { risk-seeking } \\
(\alpha=1)\end{array}$ & $\begin{array}{c}\text { risk-aversion } \\
(\alpha=0)\end{array}$ \\
\hline Human Resource Management (HRM) & $(0.569,1.48,3.185)$ & 1 & 1 & 1 \\
\hline Preventive Maintenance (PM) & $(0.577,1.418,2.714)$ & 2 & 2 & 2 \\
\hline Supply Chain Management (SCM) & $(0.519,1.201,2.58)$ & 3 & 3 & 4 \\
\hline Continuous improvement (Kaizen) & $(0.556,1.408,1.889)$ & 4 & 4 & 3 \\
\hline Failure Mode and Effect Analysis (FMEA) & $(0.433,0.97,1.602)$ & 5 & 5 & 5 \\
\hline Job Rotation & $(0.323,0.83,1.634)$ & 6 & 6 & 6 \\
\hline Pull System (kanban production control) & $(0.341,0.729,1.467)$ & 7 & 7 & 7 \\
\hline
\end{tabular}

Efficiency, simplicity and functionality of the model for any type of organizations were ascertained by implementing the model for a company. Taking into account that every organization, in the model, may use its unique regarding competitive advantage, attributes, and lean enablers, flexibility of the model is confirmed.

As recommendations for future work, using other competitive advantages, lean attributes and enablers can be studied by other works. Future works may consider other case study in manufacturing and service organizations. Moreover, the model may be studied in regarding the whole of a supply chain. An identical study aimed to achieve agility is also recommended. Finally, future studies may be concerned with employing other methods for weighting and ranking. 


\section{References}

Abdulmalek, F.A., \& Rajgopal, J. (2007). Analyzing the benefits of lean manufacturing and value stream mapping via simulation: A process sector case study. International Journal of Production Economics, 107, 223-236.

Akao, Y. (1990). Quality Function Deployment: Integrating Customer Requirements into Product Design. Productivity Press, Cambridge, MA.

Alem Tabriz, A., \& Mohammad Rahimi, A.R. (2008). Advanced production and operations management approaches. Bazargaani press.

Boender, C.G.E., de Graan, J.G., \& Lootsma, F.A. (1989). Multi-criteria decision analysis with fuzzy pairwise comparisons. Fuzzy Sets and Systems, 29, 133-143.

Bottani, E. (2009). A fuzzy QFD approach to achieve agility. International Journal of Production Economics, 119 (2), 380-391.

Bottani, E., \& Rizzi, A. (2006). Strategic management of logistics service: A fuzzy-QFD approach. International Journal of Production Economics, 103 (2), 585-599.

Browning, T.R., \& Heath, R.D. (2009). Reconceptualizing the effects of lean on production costs with evidence from the F-22 program. Journal of Operations Management, 27, 23-44.

Buckley, J.J., (1985). Fuzzy hierarchical analysis. Fuzzy Sets and Systems, 17, 233-247.

Chamodrakas, I., Alexopoulou, N., \& Martakos, D., (2009). Customer evaluation for order acceptance using a novel class of fuzzy methods based on TOPSIS. Expert Systems with Applications, 36, 7409-7415.

De Treville, S., \& Antonakis, J. (2006). Could lean production job design be intrinsically motivating? Contextual, configurational, and levels-of-analysis issues. Journal of Operations Management, 24 (2), 99-123.

Fung, R.Y.K., Popplewell, K., \& Xie, J. (1998). An intelligent hybrid system for customer requirements analysis and product attribute targets determination. International Journal of Production Research, 36 (1), 13-34.

Fung, R.Y.K., Tang, J., Tu, P.Y., \& Chen, Y. (2003). Modeling of quality function deployment planning with resource allocation. Research Engineering Design, 14, 247-255.

Hall, R.W. (1987). Attaining Manufacturing Excellence: Just-in-Time, Total Quality, Total People Involvement. Dow Jones- Irwin, Homewood, IL.

Hauser, J.R., \& Clausing, D. (1988). The House of Quality. Harvard Business Review, 63-73.

Ho, W. (2008). Integrated analytic hierarchy process and its applications - a literature review. European Journal of Operational Research, 186, 211-228.

Hopp, W.J., \& Spearman, M.L. (2004). To pull or not to pull: what is the question? Manufacturing and Service Operations Management, 6 (2), 133-138.

Khoo, L.P., \& Ho, N.C. (1996). Framework of a fuzzy quality function deployment system. International Journal of Production Research, 34 (2), 299-311.

Krafcik, J.F. (1988). Triumph of the Lean Production System. Sloan Management Review, Fall.

Kumar, S., \& Vaidya. O.S. (2006). Analytic hierarchy process: an overview of applications. European Journal of Operational Research, 169, 1-29.

Liu, H.T. (2009). The extension of fuzzy QFD: from product planning to part deployment. Expert Systems with Applications, 36, 11131-11144.

M. Bevilacqua, M., Ciarapica, F.E., \& Giacchetta, G. (2006). A fuzzy-QFD approach to supplier selection. Journal of Purchasing \& Supply Management, 12, 14-27. 
McLachlin, R. (1997). Management initiatives and just-in-time manufacturing. Journal of Operations Management, 15, 271-292.

Meredith, J.R., McTavish, R., (1992). Organized manufacturing for superior market performance. Long Range Planning, 25 (6), 63-71.

Monden, Y., (1998). Toyota Production System - An Integrated Approach to Just-in-Time. $3^{\text {rd }}$ ed. Engineering and Management Press, Norcross, Georgia.

Nahmias, S., (2001). Production and Operations Analysis. $4^{\text {th }}$ ed. McGraw Hill, New York.

Narasimhan, R., Swink, M., \& Kim, S.W., (2006). Disentangling leanness and agility: an empirical investigation. Journal of Operations Management, 24, 440-457.

Prince, J., \& Kay, J.M. (2003). Combining lean and agile characteristics: creation of virtual groups by enhanced production flow analysis. International Journal of Production Economics, 85, 305-318.

Ren, J., Yusuf, Y.Y., \& Burns, D. (2003). The effects of agile attributes on competitive priorities: a neural network approach. Integrated Manufacturing Systems, 14 (6), 489-497.

Riezebos, J. (2009). Advancing lean manufacturing, the role of IT. Computers in Industry, 60 , 235236.

Saaty, T.L. (1980). The Analytic Hierarchy Process. McGraw-Hill, New York.

Scherrer-Rathje, M., Boyle, T.A., \& Deflorin, P. (2009). Lean, take two! Reflections from the second attempt at lean implementation. Business Horizons, 52, 79-88.

Schonbergerm, R.J. (2007). Japanese production management: an evolution with mixed success. Journal of Operations Management, 25, 403-419

Shah, R., \& Ward, P.T. (2003). Lean manufacturing: context, practice bundles, and performance. Journal of Operations Management, 21, 129-149.

Shen, X.X., Tan, K.C., \& Xie, M. (2001). The implementation of quality function deployment based on linguistic data. Journal of Intelligent Manufacturing, 12, 65-75.

Sohn, S.Y., \& Choi, I.S. (2001). Fuzzy QFD for supply chain management with reliability consideration. Reliability Engineering and System Safety, 72, 327-334.

van Laarhoven, P.J.M., \& Pedrycz, W. (1983). A fuzzy extension of Saaty's priority theory. Fuzzy Sets and Systems, 11, 229-241.

Wang, Ying-Ming., Luo, Ying., (2009). Area ranking of fuzzy numbers based on positive and negative ideal points. Computers and Mathematics with Applications, 58, 1769-1779.

Wang, Y.M., Elhag, T.M.S., \& Hua, Z. (2006). A Modified fuzzy Logarithmic Least Squares Method for fuzzy analytical hierarchy process. Fuzzy set and Systems, 157, 3055-3071.

White, R.E., Pearson, J.N., \& Wilson, J.R. (1999). JIT Manufacturing: a survey of implementation in small and large US manufacturers. Management Science, 45 (1), 1-15.

Womack, J.P., \& Jones, D.T., (1996). Lean Thinking: Banish Waste and Create Wealth in Your Corporation. Simon \& Schuster, New York.

Womack, J.P., Jones, D.T., \& Ross, D. (1990). The Machine that Changed the World. Macmillan Publishing Company, Canada.

Yusuf, Y.Y., Ren, J., \& Gunasekaran, A. (2000). An integrated framework for agility-based decision making system. In: Proceedings of the Third International Conference Intelligent Manufacturing Processes and System, MIT, Cambridge.

Zadeh, L.A., (1965). Fuzzy sets. Information and Control, 8, 338-353.

Zarei, M., Fakhrzad, M.B., \& Jamali Paghaleh, M. (2011). Food supply chain leanness using a developed QFD model. Journal of Food Engineering, 102, 25-33.

Zimmermann, H.J., (1991). Fuzzy Set Theory and its Applications. second ed. Kluwer Acade 